\title{
AIDS Population
}

National Cancer Institute

\section{Source}

National Cancer Institute. AIDS Population. NCI Thesaurus. Code C18620.

Subgroups of AIDS patients. 